\title{
Mass Transfer During Vacuum Frying of Eggplant Slices (Solanum melongena L.)
}

\author{
Luis Alberto Gallo-García ${ }^{\# 1}$, Kevin José González-Morelo ${ }^{\# 2}$, Diofanor Acevedo Correa ${ }^{\# 3}$, Piedad M. \\ Montero Castillo ${ }^{\# 4}$, Jose D. Torres González ${ }^{* 5}$ \\ ${ }^{\#}$ Faculty of Engineering, Food Engineering program, Research Group NUSCA, University of Cartagena \\ Av. El Consulado, St. 30 No. 48-152. Colombia. \\ * Department of Chemical and Bioprocess Engineering, School of Engineering, Pontificia Universidad Católica \\ de Chile, Vicuña Mackenna 4860, Santiago, Chile \\ ${ }^{1}$ lgallog1992@hotmail.com, ${ }^{2}$ kevinjgonza@hotmail.com, ${ }^{3}$ diofanor3000@gmail.com, \\ pmargaritamontero@hotmail.com, jitorresg3@unicartagena.edu.co.
}

\begin{abstract}
The objective of this research was to determinate the mass transfer and oil uptake parameters during vacuum frying of eggplant slices. The frying process was made in control and blanched samples at two temperatures $\left(120{ }^{\circ} \mathrm{C}\right.$ and $\left.140{ }^{\circ} \mathrm{C}\right)$ and five frying times $(0 \mathrm{~s}, 60 \mathrm{~s}, 120 \mathrm{~s}, 180 \mathrm{~s}$, $240 \mathrm{~s}$ and $300 \mathrm{~s}$ ). The calculation of moisture transfer coefficients was determined through mass diffusion differential equations. Moisture diffusion coefficients at $120{ }^{\circ} \mathrm{C}$ and $140{ }^{\circ} \mathrm{C}$ were $8.791 \times 10^{-11} \mathrm{~m}^{2} \mathrm{~s}^{-1}$ and $1.561 \times 10^{-10} \mathrm{~m}^{2} \mathrm{~s}^{-1}$ for control samples. Oil uptake kinetic parameters such as the specific absorption rate and equilibrium oil content were $0.080 \mathrm{~s}^{-1}$ y $0.097 \mathrm{~s}^{-1}$ for control samples at $120{ }^{\circ} \mathrm{C}$ and $0.0418 \mathrm{~s}^{-1} \mathrm{y} 0.048 \mathrm{~s}^{-}$ ${ }^{1}$ at $140{ }^{\circ} \mathrm{C}$.
\end{abstract}

Keyword-Fick’s law, oil uptake, blanching, moisture, eggplant.

\section{INTRODUCTION}

Eggplant (Solanum melongena L.) is a vegetable of the Solanaceae family and represents a plant system very interesting for its composition in phytochemicals and nutraceuticals; in particular, polyphenols, such as phenolic acids and anthocyanins, which are well known for their antioxidant properties[1]. After tomato is the second most important vegetable cultivated for its fruit, it is also a crop distributed throughout the world and is the seventh in production worldwide[2].It is a food that facilitates digestion, eliminates cholesterol, is low in calories and is made up mainly of water, fiber, calcium, magnesium, phosphorus, potassium and vitamins $\mathrm{A}, \mathrm{B}$ and C[2].It is a species of great economic and social importance in the Caribbean Region, especially in Sucre, Córdoba and Bolívar, since they represent $70 \%$ of the national production, making it one of the most cultivated vegetables by peasant families in the Caribbean[3].This product is eaten grilled, cooked, stuffed, in paste and fried[1].

Frying is one of the most widely used methods in food preparation[4]. This process is a cooking method where fat or oil is used as a heat transfer medium, in direct contact with the food at a temperature above the boiling point of the water[5], [6].The purpose of this process is to give food special characteristics of smell, colour, taste and develop very particular attractive and pleasant properties such as crust formation, aromas or visual appearance[7], [8].It is one of the simplest and quickest methods of cooking food, popularity is related to the speed with which food can be cooked[2].During this operation the oil presents a large number of complex reactions that can form toxic compounds produced by lipid peroxidation reactions with hydroperoxide formation, causing health effects such as irritation and colon cancer[9].In addition, a problem associated with fried foods is the considerable absorption of oil when process times and temperatures are not controlled[10].Oil absorption is mainly a surface phenomenon and most of the oil is absorbed by the fried product in the post-frying period[10].

In order to obtain low-fat products, it is useful to understand the mechanisms involved in the frying process[11]. An alternative to reduce the oil absorption and other toxic compounds is the application of vacuum frying, where the food is fried under conditions of subatmospheric pressure in a hermetic system.In addition to this operation, other technologies have been used in conjunction with the purpose of reducing oil absorption, improving texture and colour, among these pre-treatments are blanching, freezing, osmotic dehydration, among others.

Researchers such as Troncoso \&Pedreschihave applied the Fick's diffusion law for truncated infinite plates to model water loss in fried products with good fit between experimental data and calculated values[10], [12].There is a diversity of information on modelling, both empirical and phenomenological, of moisture loss and oil absorption during vacuum frying.However, there are several reports that propose different empirical relationships to quantify changes in the physical properties of some foodstuffs during conventional frying (at atmospheric pressure), which could be used as a first approximation to predict oil absorption of the change in physical properties during vacuum frying[13]. On the other hand, the rate of oil absorption by the food is more complex, because the vapor that is present in the pores of the food stops the passage of oil into the food, and 
only when the steam output is reduced, the oil is transferred to the food, this depends on the permeability properties of the crust formed on the surface of the food[13], [14].

When the process ends, the food is removed from the oil and cooling begins, the vapour pressure decreases and a suction effect is produced, helping the oil deposited on the surface of the food to pass into the crust.Currently, the research that has been carried out in this vegetable, has been cooking[1], but it is important to note that in this food matrix has not been carried out research on the kinetic parameters of moisture and absorption of oil during the process of frying by vacuum immersion.In view of the above, the objective of this research was to determine the mass transfer coefficients of moisture and oil during vacuum frying of eggplant slices (S. melongena L.).

\section{Material AND Methods}

\section{A. Raw Material}

CriollaMorada variety eggplants (S. melongena L.)and palm oil were purchased at a local supermarket in the city of Cartagena de Indias. The eggplants were selected taking into account the size and not showing any damage by handling. The vegetable was washed and disinfected, then cut into flat leaf shape with dimensions of $0.025 \times 0.003 \times 0.05 \mathrm{~m}$ for further analysis.

\section{B. Pretreatments}

Once the vegetables were prepared, they were divided into two blocks; the first block was blanched in hot water for $2 \mathrm{~min}$ at $95^{\circ} \mathrm{C}$ in a $7 \mathrm{~L}$ capacity WNB (Germany) water bath, connected to a $220 \mathrm{~V}$ power supply and with dimensions of $240 \times 210 \times 140 \mathrm{~mm}$, which had temperature control and digital time.Immediately afterwards the samples were cooled in water at room temperature for 20 s to prevent softening. The second block was the control, which was not pre-treated.

\section{Vacuum frying conditions}

The eggplant slices were fried in a Gastrovac ${ }^{\circledR} 167$ (International Cooking Concepts, Barcelona, Spain) with the measures: $0.04 \times 0.026 \times 0.046 \mathrm{~m}$, maximum capacity of $10.5 \mathrm{~L}$ and $220 \mathrm{~V}$ voltage [15].The maximum vacuum pressure applied to the equipment was $30 \mathrm{kPa}$. To define the temperature of the frying process, two deltas were used with respect to the boiling water temperature at $30 \mathrm{kPa}: \Delta \mathrm{T} 1=50^{\circ} \mathrm{C}$ and $\Delta \mathrm{T} 2=70^{\circ} \mathrm{C}$. Therefore, the oil temperatures were $120^{\circ} \mathrm{C}$ and $140^{\circ} \mathrm{C}$. The frying times were $0 \mathrm{~s}, 60 \mathrm{~s}, 120 \mathrm{~s}, 180 \mathrm{~s}, 240 \mathrm{~s}$, and $300 \mathrm{~s}$, established by preliminary tests. The ratio of the product/oil was 1:10 weight/volume. The oil was first heated to the desired temperature, samples of eggplant slices were placed in a stainless steel basket, the lid closed and the vacuum pump activated.When the equipment reached maximum pressure, the basket was immersed in hot oil. Once the set frying time had been achieved, the basket was raised and the pump was left on for one minute, then the vacuum broke and the equipment was turned off to remove the samples. The eggplant slices were placed in a wire mesh basket and placed at room temperature for five minutes and then analysed.

\section{Moisture and oil analysis}

The moisture content of the eggplant flakes was determined by drying at $105 \pm 1{ }^{\circ} \mathrm{C}$ to constant weight[17], and the oil content was determined by Soxhlet extraction[16]. All trials were conducted in triplicate.

\section{E. Determination of moisture transfer coefficients}

Moisture content data based on frying time were used in a mathematical model to determine the moisture transfer coefficient.For this purpose, the equation of concentration as a function of time and position was used for an infinite $2 \mathrm{~L}$ thick film, which is obtained by resolving the differential diffusion equation in transient state shown in equation (1), with the boundary and initial conditions expressed in Equation (2) as Yildizet al.,[17] in potato frying, Alviset al.,[18]in yam frying and Tirado et al.,[5] in tilapia frying and breadfruit.

$\frac{\partial^{2} C}{\partial x^{2}}=\frac{1}{D} \frac{\partial C}{\partial t}, 0 \leq x \leq L$ for $t>0$

$\frac{\partial C}{\partial x}=0 x=0 ;-D \frac{\partial C}{\partial x}=k_{c}\left(C-C_{\infty}\right)$ en $x=L ; C=C_{i}$ when $t=0$

The following infinite series solution shows the concentration of moisture located at any point within the film as a function of time.

$$
\left(\frac{C(x, t)-C_{\infty}}{C_{i}-C_{\infty}}\right)=\sum_{n=0}^{n=\infty} \frac{2 \operatorname{Sen} \delta_{n}}{\delta_{n}+\left(\operatorname{Sen} \delta_{n}\right)\left(\operatorname{Cos} \delta_{n}\right)} \operatorname{Cos}\left(\delta_{n} \frac{x}{L}\right) e^{-\delta_{n}^{2 D t} \frac{D t}{L^{2}}}
$$

The reduced form of the Equation (3) can be used to obtain the solution for parallelepiped shaped sheets (finite in two dimensions), making use of the overlapping rule, according to which, the solution for the mass transfer of a 2-dimensional thin sheet is found by multiplying the solution for two infinite sheets, Equation (4), developed by Crank [19]. 
$\left(\frac{C(x, y, t)-C_{\infty}}{C_{i}-C_{\infty}}\right)_{\text {finite sheet }}=\left(\frac{C(x, t)-C_{\infty}}{C_{i}-C_{\infty}}\right)_{\text {infinite sheet } 2 L}\left(\frac{C(y, t)-C_{\infty}}{C_{i}-C_{\infty}}\right)_{\text {infinite sheet } 2 L}$

Where $\mathrm{C}(x, y, t)$ is the concentration of moisture at any point and at any time, $\left(\mathrm{kg} \mathrm{kg} \mathrm{solids}{ }^{-1}\right)$. Replacing in (4) for infinite plates of finite thickness in $x$ and $y$, the Equation (5) and (6).

$$
\begin{aligned}
& \left(\frac{C(x, t)-C_{\infty}}{C_{i}-C_{\infty}}\right)=\frac{2 \operatorname{Sen} \delta_{n}}{\delta_{n}+\left(\operatorname{Sen} \delta_{n}\right)\left(\operatorname{Cos} \delta_{n}\right)} \operatorname{Cos}\left(\delta_{n} \frac{x}{L}\right) e^{-\delta_{m}^{2} \frac{D t}{L^{2}}} \\
& \left(\frac{C(y, t)-C_{\infty}}{C_{i}-C_{\infty}}\right)=\frac{2 \operatorname{Sen} \delta_{n}}{\delta_{n}+\left(\operatorname{Sen} \delta_{n}\right)\left(\operatorname{Cos} \delta_{n}\right)} \operatorname{Cos}\left(\delta_{n} \frac{y}{L}\right) e^{-\delta_{m}^{2} \frac{D t}{L^{2}}}
\end{aligned}
$$

Taking only the first term of Equation (3) for calculations related to mass transfer, these equations were integrated across the entire volume, since mass transfer in general results were obtained experimentally across the entire volume rather than at a certain location and integrating it with respect to volume $\left(\frac{1}{V} \int_{o}^{V} C(x, t) d V\right)$, Equation (7).

$\left(\frac{C(x, t)-C_{\infty}}{C_{i}-C_{\infty}}\right)\left(\frac{C(y, t)-C_{\infty}}{C_{i}-C_{\infty}}\right)=E e^{\left(-\delta_{n}^{2} \frac{D_{a} t}{L^{2}}\right)}$

Where:

$E=\frac{2 \operatorname{Sen}^{2} \delta_{n}}{\delta_{n}\left[\delta_{n}+\left(\operatorname{Sen} \delta_{n}\right)\left(\operatorname{Cos} \delta_{n}\right)\right]}$

Linearizing Equation (7), the Equation (9):

$\ln \left(\frac{\bar{C}(x, y, t)-C_{\infty}}{C_{i}-C_{\infty}}\right)=2 \ln E-2 \delta_{n}^{2} \frac{D_{a} t}{L^{2}}$

By graphing $\operatorname{Ln}\left(\frac{\bar{C}(x, y, t)-C_{\infty}}{C_{i}-C_{\infty}}\right)$ vs.t, from the graph intercept the first root of the characteristic equation $\left(\delta_{\mathrm{n}}\right)$ was calculated using the Matlabfzero function. The coefficient of diffusion $\mathrm{Da}\left(\mathrm{m}^{2} \mathrm{~s}^{-1}\right)$ was then determined from the slope of the linear section of this graph that equals $-2 \delta_{n}^{2} \frac{D_{a}}{L^{2}}$. Once found, $\mathrm{Bi}_{\mathrm{m}}$ was determined and then $\mathrm{k}_{\mathrm{c}}$.

$B i_{m}=\delta_{n} \operatorname{Tan} \delta_{n}$

$B i_{m}=\frac{k_{c} L}{D_{a}}$

\section{F. Oil uptake kinetics}

Empirical relationships are often used to describe the absorption of oil during frying. The relationship used in this study was described by Moyano and Pedreschi[11], using Equation (12).

$O=\frac{O_{e q} k t}{1+k t}$

Where $\mathrm{O}$ is the oil content in time $t$ (free oil, on dry basis), $\mathrm{O}_{\mathrm{eq}}$ is the oil content in equilibrium (or maximum content) (free oil, on dry basis) at time $t=\infty, k$ represents the specific absorption rate for this model.The calculation of the activation energy was found to be dependent on the temperature dependency of moisture diffusivity using an Arrhenius equation.

$D=D_{0} e^{\left(\frac{-E a}{R T}\right)}$

Where $\mathrm{D}_{0}$ represents the pre-exponential factor associated with the collision factor in terms of absolute reaction speed, $\mathrm{E}_{\mathrm{a}}$ is the activation energy $\left(\mathrm{kJ} \mathrm{mol}^{-1}\right), \mathrm{R}$ is the constant of the perfect gases $\left(8.31441 \mathrm{~kJ} \mathrm{kmol}^{-1} \mathrm{~K}^{-1}\right)$ and $\mathrm{T}$ is the temperature $(\mathrm{K})$.

\section{G. Statistical Analysis}

A completely randomized $5 \times 2^{2}$ factorial design was performed, with three independent factors, including two levels (control and blanching), temperature $\left(120^{\circ} \mathrm{C}\right.$ and $\left.140^{\circ} \mathrm{C}\right)$, and five time levels $(0,60,120,180,240$, and 300 s).For data analysis, a variance analysis was performed using Statgraphics (Statgraphics Centurion Version 16.1.15, Chicago, EE. UU)[20]. The level of statistical significance used was 5\%. All the experiments were conducted in triplicate. 


\section{III.RESULTS AND DISCUSSIONS}

Fig. 1 and 2 show the dimensionless ratio of moisture concentration vs. time, obtained during vacuum eggplant frying. The slopes of the linear sections of these graphs were obtained by means of linear regression analysis. The rate of water loss was higher as the oil temperature increased.It is evident that the rate of moisture loss from the food increased with time and frying temperature. Once this was done, the number of biot used to determine the mass transfer coefficient was calculated.

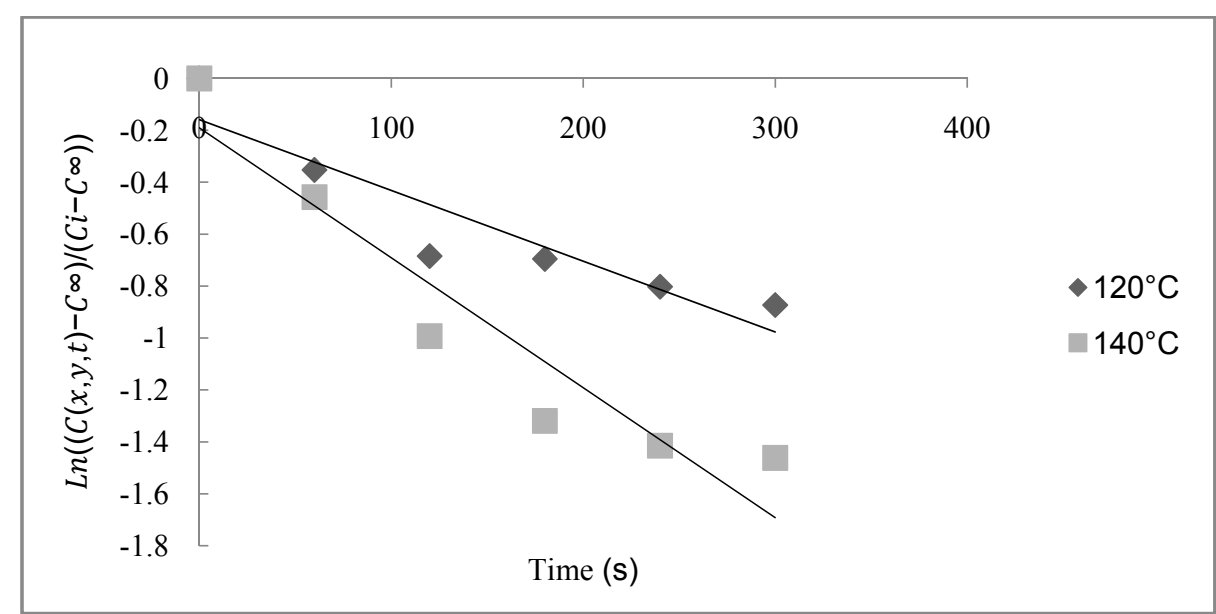

Fig. 1. Linear section of the dimensionless ratio moisture vs. time in eggplant control samples.

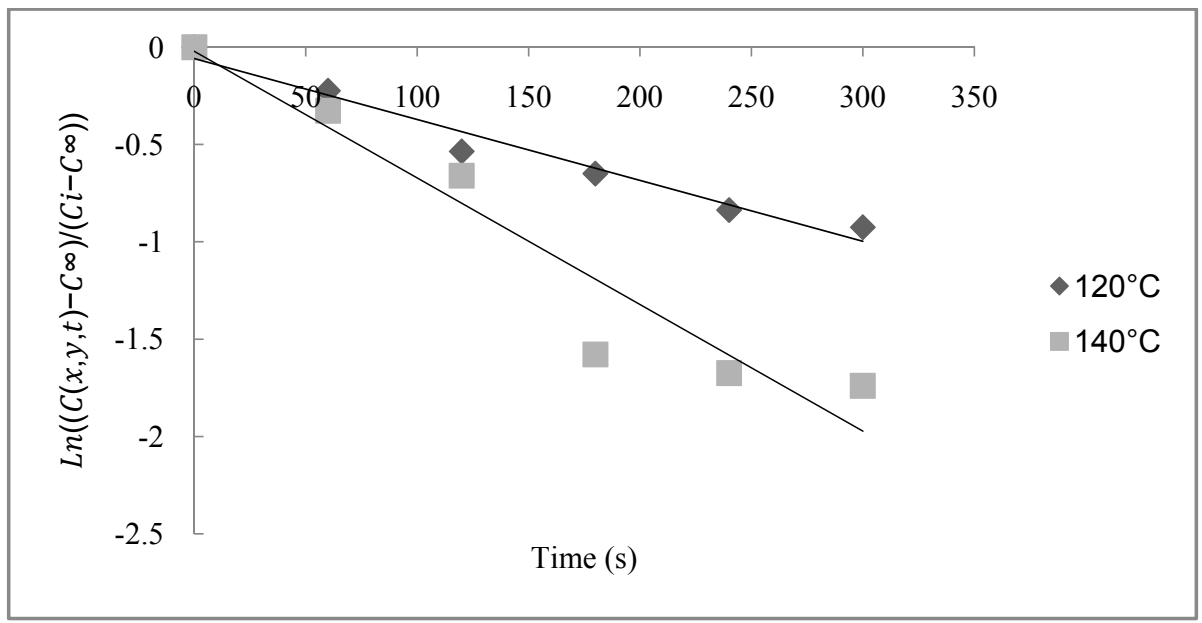

Fig. 2. Linear section of the dimensionless moisture vs. time ratio in blanched eggplants.

Table 1 shows the diffusion coefficients, numbers of biot, mass transfer coefficients and activation energies. $\mathrm{D}_{\mathrm{a}}$ and $\mathrm{k}_{\mathrm{c}}$ increased with temperature for both treatments, as did activation energy.Soorgi et al.,[21] reported effective diffusivity values for samples of chicken nuggets pre-treated with meticellulose immersion, ranging from $1.43 \times 10-8 \mathrm{~m}^{2} \mathrm{~s}^{-1}$ to $3.25 \times 10^{-8} \mathrm{~m}^{2} \mathrm{~s}^{-1}$.

Table 1. Mass transfer parameters as a function of oil temperature

\begin{tabular}{|c|c|c|c|c|c|}
\hline Treatments & $\mathbf{T}\left({ }^{\circ} \mathbf{C}\right)$ & $\mathbf{D}_{\mathbf{a}}$ & $\left.\mathbf{( B}_{\mathbf{i}}\right)$ & $\mathbf{K}_{\mathbf{c}}$ & $\mathbf{E}_{\mathbf{a}}\left(\mathbf{k J ~ m o l}^{-1} \mathbf{)}\right.$ \\
\hline \multirow{3}{*}{ Control } & 120 & $8.791 \mathrm{E}-11$ & 2.45 & $7.169 \mathrm{E}-08$ & \multirow{2}{*}{38.75} \\
\cline { 2 - 5 } & 140 & $1.561 \mathrm{E}-10$ & 2.55 & $1.328 \mathrm{E}-07$ & \\
\hline \multirow{3}{*}{ Blanching } & 120 & $1.157 \mathrm{E}-10$ & 2.13 & $8.217 \mathrm{E}-08$ & \multirow{2}{*}{51.29} \\
\cline { 2 - 5 } & 140 & $2.474 \mathrm{E}-10$ & 2.02 & $1.669 \mathrm{E}-07$ & \\
\hline
\end{tabular}

Adedejiet al., [22] reported values in the range of $6.39 \times 10^{-10} \mathrm{~m}^{2} \mathrm{~s}^{-1}$ to $15.47 \times 10^{-10} \mathrm{~m}^{2} \mathrm{~s}^{-1}$ for chicken nuggets, while Troncoso and Pedreschi[10] found values of $8.57 \times 10^{-9} \mathrm{~m}^{2} \mathrm{~s}^{-1}$ to $2.95 \times 10^{-8} \mathrm{~m}^{2} \mathrm{~s}^{-1}$ for fried potatoes. Also Amiryousefiet al.,[23] reported effective diffusivity values ranging from $1.47 \times 10^{-8}$ to $4.17 \times 10^{-8} \mathrm{~m}^{2} \mathrm{~s}^{-1}$ for frying meat plates.It is important to point out that vacuum frying could generate a significant hydrodynamic gradient that could affect the microstructure of the product, and consequently its physical-chemical and transport properties[10].Regarding activation energy, a range between $13.65 \mathrm{~kJ} \mathrm{~mol}^{-1}$ and $54.63 \mathrm{~kJ} \mathrm{~mol}^{-1}$ was presented by 
Adedejiet al.,[22] for the diffusion of moisture in chicken nuggets. Troncoso and Pedreschi[10] reported this parameter between $23.5 \mathrm{~kJ} \mathrm{~mol}^{-1}$ and $29.3 \mathrm{~kJ} \mathrm{~mol}^{-1}$ for potato slices. Being close to those reported in this study.Amiryousefiet al.,[23] found that the activation energy obtained by the Arrhenius equation for effective diffusivity against moisture ranged from $38.84 \mathrm{~kJ} \mathrm{~mol}^{-1}$ to $51.07 \mathrm{~kJ} \mathrm{~mol}^{-1}$ in fried ostrich meat.High activation energies are typically found in materials with low moisture content due to a strong substrate-water interaction[10]. In other words, as the activation energy increases, the more difficult it will be to remove water from the food.

\section{A. Oil transfer kinetics}

Table 2 shows the specific absorption rate and oil content in equilibrium. Certainly, the frying conditions, sample dimensions (especially thickness), product type, and pre-treatments are important parameters that determine the constant speed of oil absorption.In all the cases studied, the specific rate increased with frying temperature, but the $\mathrm{O}_{\mathrm{eq}}$ equilibrium oil content decreased. This behaviour can be explained by the fact that higher frying temperatures lead to higher oil absorption[24].

Table 2. Oil uptake kinetic parameters

\begin{tabular}{|c|c|c|c|c|}
\hline \multirow{2}{*}{ Pretreatments } & \multicolumn{2}{|c|}{$\mathbf{K ~ s}^{\mathbf{- 1}}$} & \multicolumn{2}{c|}{$\mathbf{O}_{\text {eq }}{\text { (g absorbed oil } \times \mathbf{g ~ o f S o l i d s}^{\mathbf{- 1}} \text { ) }}$} \\
\cline { 2 - 5 } & $120^{\circ} \mathrm{C}$ & $140^{\circ} \mathrm{C}$ & $120^{\circ} \mathrm{C}$ & $140^{\circ} \mathrm{C}$ \\
\hline Control & 0.080 & 0.097 & 0.621 & 0.563 \\
\hline Blanching & 0.0418 & 0.048 & 0.532 & 0.435 \\
\hline
\end{tabular}

Adedeji et al.,[22] reported velocity constant values in the range of 0.04-40.96 s-1 for coating fried chicken nugget empanadas at $170^{\circ} \mathrm{C}, 180^{\circ} \mathrm{C}$ and $190^{\circ} \mathrm{C}$. Amiryousefiet al., [23] reported values in the range of 0.024$19.708 \mathrm{~s}^{-1}$ for microwave fried pre-treated ostrich meat slices between $130^{\circ} \mathrm{C}$ and $160^{\circ} \mathrm{C}$.Duran et al., [25] presented a range of values of $0.185-0.219 \mathrm{~s}^{-1}$ for potato chips between $120^{\circ} \mathrm{C}$ and $180^{\circ} \mathrm{C}$, similar to those reported in this study.Fig. 3 shows the oil absorption kinetics of samples of control and blanched eggplants at different temperatures. It is illustrated that as the frying temperature increased independent of pretreatment and time, the oil gain was higher.However, with previous blanching the slices of eggplants showed a reduction in oil absorption of $23.21 \%$ and $14.51 \%$ with respect to the control at $120^{\circ} \mathrm{C}$ and $140^{\circ} \mathrm{C}$, respectively.

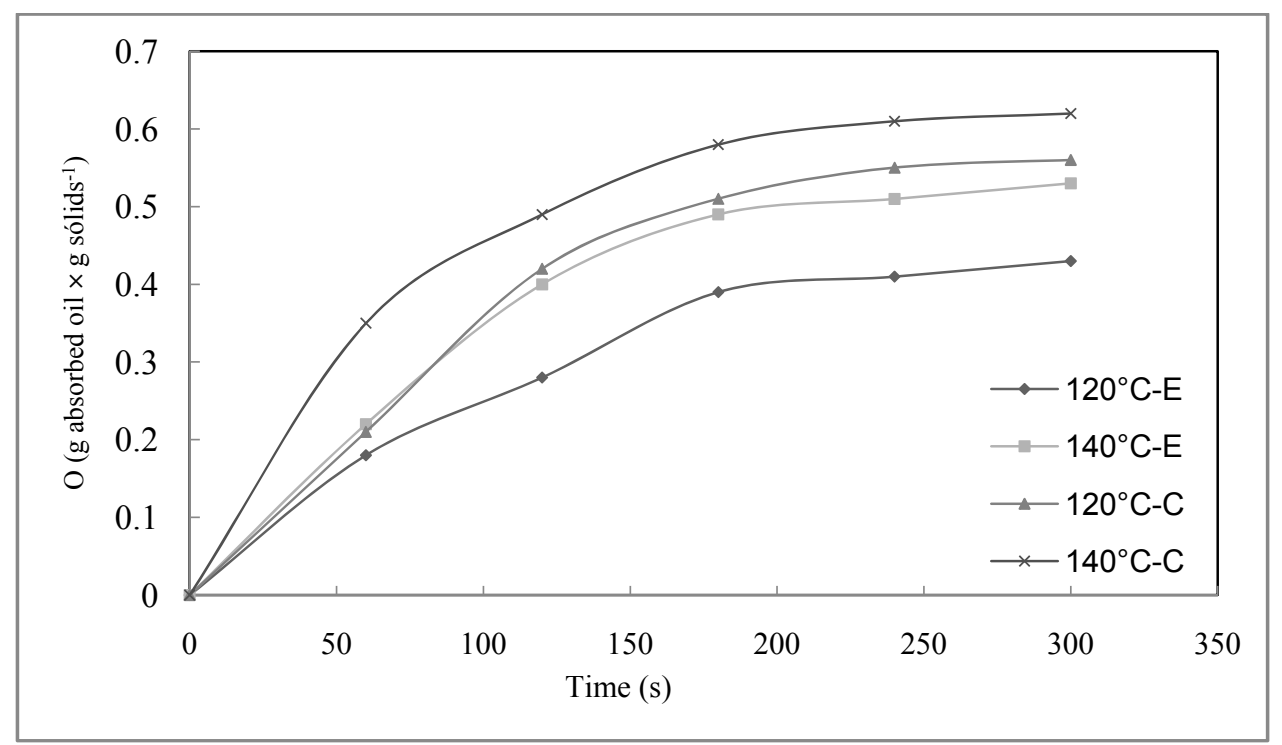

Fig. 3. Oil absorption in control (C) and blanched eggplant samples (E).

The oil absorption mechanism may be related to the capillary pressure difference and the interfacial tension between oil and water vapor within pores[24].Alvarez et al., [26] found that blanching at high temperatures and short times (e. g. $97^{\circ} \mathrm{C}, 2 \mathrm{~min}$ ) before frying potato strips resulted in a higher oil content than fresh strips, which is undesirable for consumer acceptance. However, some authors reported that low temperature blanching (e. g. between $55^{\circ} \mathrm{C}$ and $70^{\circ} \mathrm{C}$ ) prior to frying activates the enzyme pectinesterase and the resulting reactions decrease porosity and therefore reduce oil absorption[7].On the other hand, at higher frying temperatures, oil absorption is generally reduced, as the process is shorter and the formation of the improved crust acts as a physical barrier to oil penetration[7]. The oil absorption rate constants depended on the main process variables such as oil temperature, product type, applied pre-treatment, type frying, product with and oil type[10], [23]. 


\section{IV.CONCLUSIONS}

The rate of moisture loss from the food was observed to have increased over time and at frying temperature. It was also illustrated that the diffusion and mass transfer coefficient increased as the temperature increased. On the other hand, regardless of the pre-treatment, oil absorption was increased at higher temperatures.Also for all cases studied, the specific absorption rate increased with frying temperature, however the Oeq equilibrium oil content decreased, and was lower in blanched samples.

\section{ACKNOWLEDGMENT}

The authors are grateful to the University of Cartagena for the financial support to the project "Plan de desarrollo para la obtención de recursosfinancieros en apoyo al fortalecimiento y sostenibilidad" that was granted to the Research Group Nutrición, Salud y CalidadAlimentaria (NUSCA).

\section{REFERENCES}

[1] R. Lo Scalzo et al., "Cooking influence on physico-chemical fruit characteristics of eggplant (Solanum melongena L.)," Food Chem., vol. 194, pp. 835-842, Mar. 2016.

[2] M. de la O. Plazas-Ávila, "Caracterización y mejora genética de la berenjena (Solanum melongena) para compuestos bioactivos," Universitat Politècnica de València, Valencia (Spain), 2015.

[3] E. Correa, H. Araméndiz, L. Azeredo, C. Pombo, and C. Cardona, "Tipificación De Comercializadores De Berenjena En Zonas Productoras Del Caribe Colombiano," Temas Agrar., vol. 15, no. 2, pp. 46-57, 2010.

[4] A. M. Gazmuri and P. Bouchon, "Analysis of wheat gluten and starch matrices during deep-fat frying," Food Chem., vol. 115, no. 3, pp. 999-1005, Aug. 2009.

[5] D. F. Tirado, D. Acevedo, and P. M. Montero, "Transferencia de Calor y Materia durante el Proceso de Freído de Alimentos: Tilapia (Oreochromis niloticus) y Fruta de Pan (Artocarpuscommunis)," Inf. Tecnológica, vol. 26, pp. 85-94, 2015.

[6] S.-D. Chen, H.-H. Chen, Y.-C. Chao, and R.-S. Lin, "Effect of batter formula on qualities of deep-fat and microwave fried fish nuggets," J. Food Eng., vol. 95, no. 2, pp. 359-364, Nov. 2009.

[7] D. Dana and I. S. Saguy, "Review: Mechanism of oil uptake during deep-fat frying and the surfactant effect-theory and myth," Adv. Colloid Interface Sci., vol. 128-130, pp. 267-272, Dec. 2006.

[8] M. Coronel, "Fritura al Vacío: Un enfoque nutricional.," Enfoque UTE, vol. 5, no. 3, pp. 1-15, 2014.

[9] T. A. Esan, O. P. Sobukola, L. O. Sanni, H. A. Bakare, and L. Munoz, "Process optimization by response surface methodology and quality attributes of vacuum fried yellow fleshed sweetpotato (Ipomoea batatas L.) chips," Food Bioprod. Process., vol. 95, pp. 27-37, Jul. 2015.

[10] E. Troncoso and F. Pedreschi, "Modeling water loss and oil uptake during vacuum frying of pre-treated potato slices," LWT - Food Sci. Technol., vol. 42, no. 6, pp. 1164-1173, Jul. 2009.

[11] P. Moyano and F. Pedreschi, "Kinetics of oil uptake during frying of potato slices: Effect of pre-treatments," LebensmittelWissenschaftund-Tech., vol. 39, no. 1, pp. 285-291, 2006

[12] J. Li, T. Zhang, Y. Liu, and L. Fan, "Effects of Initial Pore Diameter on the Oil Absorption Behavior of Potato Chips during Frying Process," J. Oleo Sci., vol. 65, no. 4, pp. 303-310, 2016.

[13] F. Pedreschi, P. Hernandez, C. Figueroa, and P. Moyano, "Modeling Water Loss During Frying of Potato Slices," Int. J. Food Prop., vol. 8, no. 2, pp. 289-299, May 2005.

[14] R. G. Moreira, M. E. Castell-Perez, and M. Barrufet, Deep Fat Frying: Fundamentals and Applications. Springer US, 1999.

[15] C. V. Yagua and R. G. Moreira, "Physical and thermal properties of potato chips during vacuum frying," J. Food Eng., vol. 104, no. 2, pp. 272-283, May 2011.

[16] P. García-Segovia, A. M. Urbano-Ramos, S. Fiszman, and J. Martínez-Monzó, "Effects of processing conditions on the quality of vacuum fried cassava chips (ManihotesculentaCrantz)," LWT - Food Sci. Technol., vol. 69, pp. 515-521, Jun. 2016.

[17] AOAC, Official methods of analysis of AOAC International. AOAC International., 18th ed. 2005.

[18] A. Yıldız, T. KorayPalazoğlu, and F. Erdoğdu, "Determination of heat and mass transfer parameters during frying of potato slices," J. Food Eng., vol. 79, no. 1, pp. 11-17, Mar. 2007.

[19] A. Alvis, L. E. Cortés, and M. Páez, "Transferencia de Calor y Materia durante la Fritura de Trozos de Ñame (Dioscórea alata)," Inf. tecnológica, vol. 20, no. 1, pp. 99-109, 2009.

[20] J. Crank, The Mathematics of Diffusion, 2nd ed. Oxford Univerity Press, 1975.

[21] Statgraphics, "Statpgraphics Centurion Statpoint technologies Inc." 2009.

[22] M. Soorgi, M. Mohebbi, S. M. Mousavi, and F. Shahidi, "The Effect of Methylcellulose, Temperature, and Microwave Pretreatment on Kinetic of Mass Transfer During Deep Fat Frying of Chicken Nuggets," Food Bioprocess Technol., vol. 5, no. 5, pp. 1521-1530, Jul. 2012.

[23] A. A. Adedeji, M. O. Ngadi, and G. S. V. Raghavan, "Kinetics of mass transfer in microwave precooked and deep-fat fried chicken nuggets," J. Food Eng., vol. 91, no. 1, pp. 146-153, Mar. 2009.

[24] M. R. Amiryousefi, M. Mohebbi, and F. Khodaiyan, "Kinetics of Mass Transfer in Microwave Precooked and Deep-Fat Fried Ostrich Meat Plates," Food Bioprocess Technol., vol. 5, no. 3, pp. 939-946, Apr. 2012.

[25] R. Yamsaengsung and R. G. Moreira, "Modeling the transport phenomena and structural changes during deep fat frying," J. Food Eng., vol. 53, no. 1, pp. 11-25, Jun. 2002

[26] M. Durán, F. Pedreschi, P. Moyano, and E. Troncoso, "Oil partition in pre-treated potato slices during frying and cooling," J. Food Eng., vol. 81, no. 1, pp. 257-265, Jul. 2007.

[27] M. D. Alvarez, M. J. Morillo, and W. Canet, "Characterization of the frying process of fresh and blanched potato strips using response surface methodology,” Eur. Food Res. Technol., vol. 211, no. 5, pp. 326-335, Oct. 2000. 